\title{
Sistem Repositori Tugas Akhir Mahasiswa dengan Fungsi Peringkat Okapi BM25
}

\author{
Ellysa Tjandra ${ }^{1}$, Monica Widiasri ${ }^{2)}$ \\ ${ }^{1) 2)}$ Jurusan Teknik Informatika, Fakultas Teknik, Universitas Surabaya \\ Raya Kalirungkut, Surabaya \\ ${ }^{1)}$ ellysa@staff.ubaya.ac.id \\ ${ }^{2)}$ monica@staff.ubaya.ac.id
}

\begin{abstract}
$\overline{\text { Abstrak- Saat ini Jurusan Teknik Informatika Universitas ' } \mathrm{X} \text { ' mewajibkan mahasiswa yang telah selesai }}$ tugas akhir untuk mengumpulkan hasil karya mereka dalam bentuk softcopy (CD) yang berisi program aplikasi dan dokumentasi, serta hardcopy (dalam bentuk buku laporan dan jurnal). Karya tersebut disimpan di perpustakaan secara fisik dan beberapa data disimpan di Digital Library Universitas ' $X$ '. Namun keterbatasan sistem yang ada saat ini menyebabkan kesulitan pencarian hasil karya tugas akhir, karena teknik/metode yang digunakan untuk melakukan pencarian dibuat dalam bentuk query sederhana dengan kriteria yang masih terbatas, tanpa pengurutan dengan peringkat. Selain itu, kepala lab di jurusan juga menemui kesulitan dalam melakukan pemetaan bidang keahlian dari tugas akhir yang dikerjakan oleh mahasiswa di masing-masing lab. Berbagai permasalahan tersebut melatarbelakangi penelitian ini, sehingga diperlukan adanya sistem yang dapat membantu jurusan dalam menyimpan hasil karya tugas akhir mahasiswa, mempermudah pencarian, serta menampilkannya. Pencarian tugas akhir pada penelitian ini berdasarkan query yang diinput oleh pengguna menggunakan metode pencarian fungsi Okapi BM25. Dengan fungsi peringkat Okapi BM25 maka hasil karya dapat ditampilkan dengan urutan peringkat sesuai relevansinya.
\end{abstract}

Kata Kunci- repositori, tugas akhir, Okapi, BM25

Abstract - Every student in Department of Informatics University ' $\mathrm{X}$ ' who has completed final project must submit their work in both softcopy (CD) - which containing the documentation and application software - and hardcopy, containing final project documentation and journal report. Currently students hardcopies are stored physically in the university library and some information are stored in the Digital Library System of University ' $X$ '. But there are some difficulties of finding those information in the current system. The system only use simple query method with very limited criteria. The query results are being displayed by the system without any ranking method. In addition, Kalab (lab manager in the department) also encountered difficulties in mapping expertise areas of students final project in their lab. The purpose of this research aims to build a repository system to help the department to store students final project results, also makes it easy to search, display, and being managed. The system also clusters, ranks and displays a set of students final project documents according to some given queries using Okapi BM25 function.

Keywords- repository, final project, Okapi, BM25

Article history:

Received 3 March 2016; Received in revised form 10 August 2016; Accepted 10 August 2016; Available online 28 October 2016

\section{PENDAhuluan}

Saat ini Jurusan Teknik Informatika Universitas ' $\mathrm{X}$ ' mewajibkan mahasiswa yang telah selesai tugas akhir untuk mengumpulkan hasil karya tugas akhir sebagai salah satu syarat kelulusan. Hasil karya Tugas Akhir mahasiswa biasanya berupa buku laporan serta program aplikasi. Setelah proses revisi tugas akhir selesai dilakukan, mahasiswa wajib mengumpulkan program aplikasi dan dokumentasi Tugas Akhir dalam bentuk softcopy (CD) yang diserahkan ke jurusan dan perpustakaan, serta hardcopy (buku dan jurnal) yang diserahkan ke perpustakaan. CD yang dikumpulkan disimpan di dalam rak dan tidak di-back up. Namun cara ini dirasa kurang efisien, karena CD memiliki batasan umur tertentu, sehingga rawan terjadi kerusakan. Selain itu mahasiswa atau dosen juga menemui kesulitan dalam mencari file karya tugas akhir mahasiswa yang pernah dikerjakan, karena harus mencari satu-persatu di kumpulan CD yang ada.

Saat ini karya tugas akhir dalam bentuk buku dan jurnal disimpan di perpustakaan Universitas ' $X$ ' secara fisik, dan beberapa data disimpan di sistem Digital Library Universitas ' $X$ ' untuk memudahkan pencarian, namun keterbatasan sistem yang ada saat ini menyebabkan mahasiswa maupun dosen yang ingin melakukan pencarian hasil karya tugas akhir menemui kesulitan, karena teknik/metode yang digunakan untuk melakukan pencarian dibuat dalam bentuk query sederhana dan kriteria yang masih terbatas, berupa judul, pembimbing, dan tanggal pengajuan saja, selain itu urutan karya yang ditampilkan juga tidak berdasarkan peringkat apapun. Hal ini membuat proses pencarian sangat terbatas, selain itu juga tidak bisa diketahui nilai tugas akhir yang diperoleh mahasiswa, padahal kriteria nilai yang 
diperoleh mahasiswa cukup signifikan dalam memperoleh hasil karya mahasiswa yang berkualitas.

Selain permasalahan tersebut, Ketua Laboratorium (Kalab) juga menemui kesulitan mengetahui pemetaan bidang keahlian dari topik tugas akhir mahasiswa di masing-masing laboratorium. Pemetaan bidang keahlian ini diperlukan untuk melakukan kategorisasi bidang keahlian tugas akhir di jurusan.

Berbagai permasalahan tersebut melatarbelakangi penelitian ini, sehingga diperlukan sistem repositori tugas akhir yang dilengkapi dengan fungsi peringkat Okapi BM25 untuk mempermudah pencarian data hasil karya tugas akhir.

\section{Metodologi Penelitian}

Metodologi penelitian ini dilakukan melalui 4 (empat) tahapan, yaitu tahap persiapan, pembuatan sistem repositori, implementasi fungsi peringkat Okapi BM25 ke dalam sistem repositori, serta evaluasi sistem. Tahapan metode penelitian dapat dilihat pada Gambar 1.

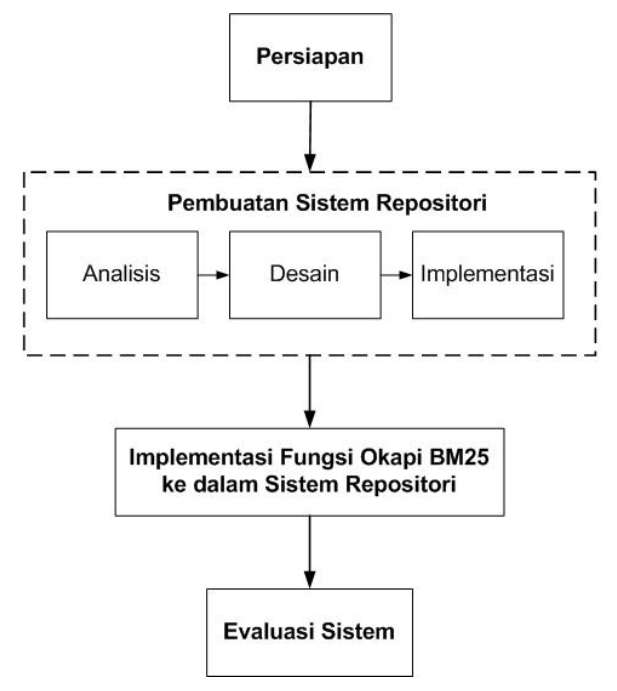

Gambar 1. Metodologi Penelitian

Pertama pada tahap persiapan dilakukan pengumpulan data dengan mempelajari sumber pustaka yang relevan. Pada tahap berikutnya dilakukan pembuatan sistem repositori tugas akhir, dimana dalam tahap ini dilakukan analisis kebutuhan sistem (melalui survey kuisioner terhadap mahasiswa, dosen, dan Kalab), kemudian luaran dari proses analisis ini menjadi input dalam proses desain perangkat lunak, meliputi desain data dan desain proses. Hasil dari desain kemudian digunakan dalam implementasi sistem dalam bentuk perangkat lunak aplikasi sistem repositori. Setelah sistem repositori terbentuk maka dilakukan implementasi fungsi Okapi BM25 ke dalam sistem terhadap fitur pencarian hasil karya tugas akhir, sehingga peringkat hasil karya yang ditampilkan dapat lebih baik karena sesuai dengan relevansinya.

\section{PEMBUATAN Sistem REPOSITORI}

Repositori adalah sebuah basis data yang digunakan bersama yang memuat informasi mengenai objek yang dihasilkan atau digunakan oleh suatu organisasi, misalnya perangkat lunak, dokumen, peta, sistem informasi, maupun komponen diskrit dari sistem produksi. Objek tersebut umumnya disimpan dalam berbagai sistem penyimpanan (storage), dan deskripsi dari objek tersebut disimpan dalam repositori. Dalam repositori umumnya juga terdapat informasi lokasi, sejarah revisi, proses pembuatan, pengaturan hak akses, serta beberapa informasi penting lain yang berhubungan dengan objek yang disimpan. Selain itu, sebuah sistem repositori juga mengatur sistem checkout/checkin (berupa fasilitas unggah/unduh informasi), konfigurasi versi, notifikasi, manajemen konten, dan aliran proses (Bernstein \& Dayal, 1994).

Pada tahun 2010, Gavrilis beserta rekan menciptakan suatu sistem manajemen repositori berbasis open source yang diberi nama Mopseus, yang menyediakan skema definisi metadata yang cukup baik, dan memiliki mekanisme migrasi data dari repositori lain. Dengan adanya fitur ini maka akan lebih memudahkan pihak penyedia informasi dalam melakukan manajemen konten (Gavrilis, Angelis, \& Papatheodorou, 2010).

Tanpa adanya sistem repositori, maka informasi penting akan sulit diakses, baik oleh komunitas yang lebih luas maupun oleh si pembuat sendiri. Dengan bantuan sistem repositori, maka tantangan ini akan dapat teratasi, tentunya dengan tetap memperhatikan privasi dan hak cipta si pembuat informasi (Dima, et al., 2012).

Untuk membangun sebuah sistem repositori, maka diperlukan proses analisis kebutuhan sistem Analisis kebutuhan sistem dilakukan dengan melakukan survey menggunakan kuisioner dengan responden 40 orang mahasiswa, 3 orang dosen, dan 2 orang Kalab, dengan tujuan merumuskan kebutuhan sistem repositori. Berdasarkan hasil survey terhadap mahasiswa, dosen, dan Kalab, diperoleh kebutuhan sistem repositori dalam bentuk fitur-fitur sistem repositori, antara lain Fitur Input Data Hasil Sidang Tugas Akhir (diakses khusus oleh PAJ setelah mahasiswa maju Sidang Tugas Akhir dan dinyatakan lulus sidang, Fitur Galeri untuk menampilkan hasil karya Tugas Akhir, Fitur Pencarian Hasil Karya Tugas Akhir, Fitur untuk mengunggah, mengunduh Hasil Karya Tugas Akhir, Fitur untuk mengunggah dan mengunduh file lain terkait Tugas Akhir, Fitur untuk mencetak dokumen atau form terkait pelaksanaan Tugas Akhir, Fitur Verifikasi Hasil Karya yang akan diunggah (khusus untuk hak akses administrator dan dosen pembimbing), Fitur 
Pengumuman Informasi Terkait Tugas Akhir, Fitur Notifikasi untuk Verifikasi Hasil Karya, Fitur Penambahan Bidang Keahlian Baru, serta Fitur Laporan Pemetaan Hasil Karya Berdasarkan Bidang Keahlian di Tiap Laboratorium.

Setelah diketahui secara pasti kebutuhan dari sistem maka kemudian dilakukan desain data. Hasil desain data sistem repositori dalam bentuk ER-Diagram dapat dilihat pada Gambar 2.

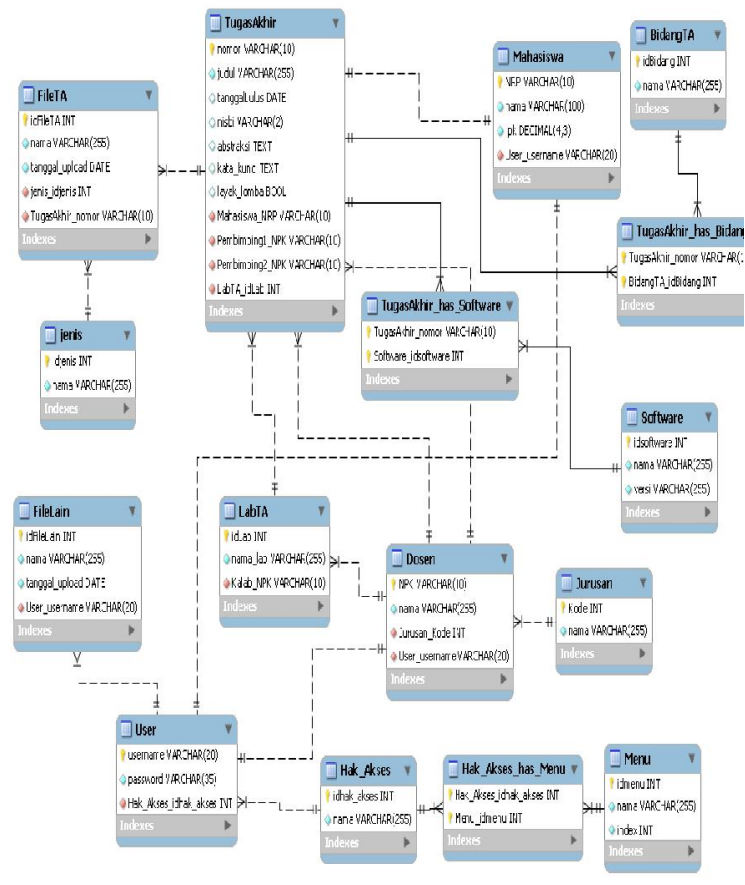

Gambar 2. ER-Diagram Sistem Repositori

Selain desain data, diperlukan pula desain proses untuk sistem repositori. Desain proses dibuat menggunakan Data Flow Diagram, yang terbagi menjadi 2 (dua) level. Hasil dari desain proses berupa Context Diagram dan DFD Level 1 dari Sistem Repositori dapat dilihat pada Gambar 3 dan Gambar 4.

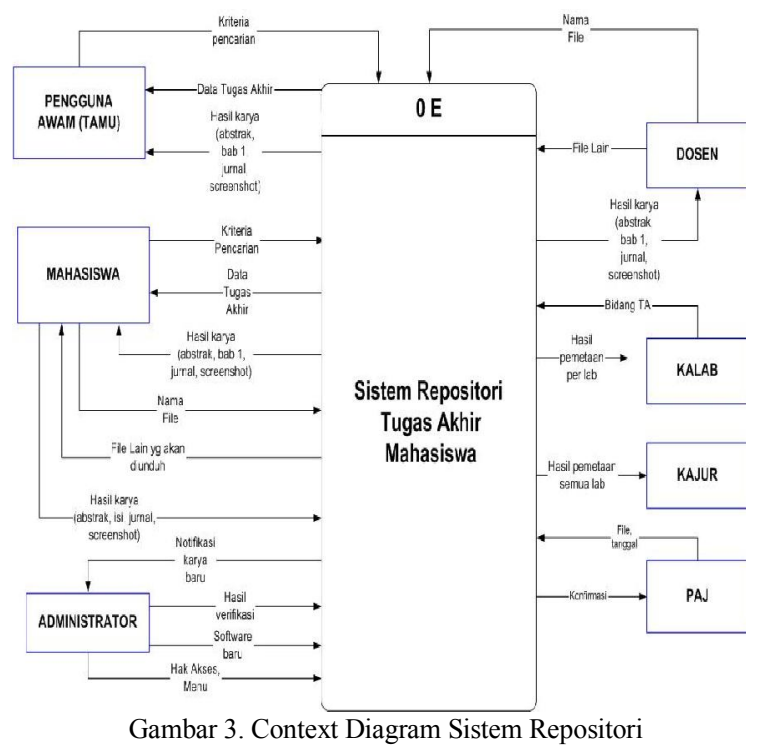

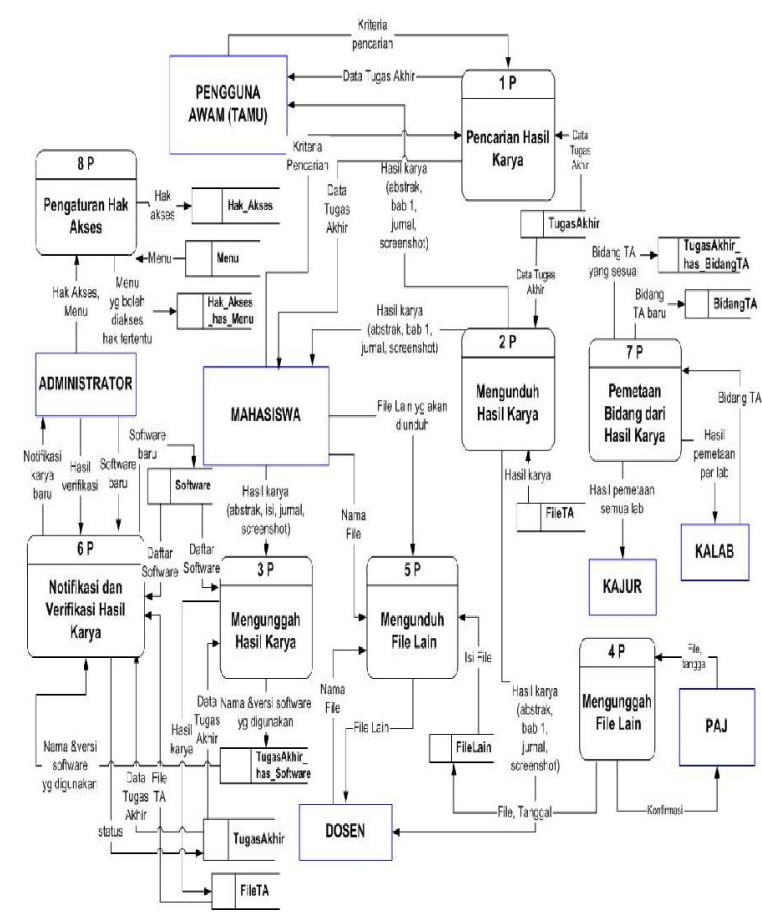

Gambar 4. DFD Level 1 Sistem Repositori

Setelah menyelesaikan fase desain, sistem repositori kemudian diimplementasikan menggunakan PHP, CodeIgniter, dan menggunakan DBMS MySql. Contoh hasil implementasi dapat dilihat pada Gambar 5 dan 6.

Mahasiswa dapat mengunggah hasil karya tugas akhir di halaman Unggah Berkas Tugas Akhir, seperti pada Gambar 5. Yang diupload tidak hanya dokumentasi, melainkan juga program aplikasi yang dibuat dalam tugas akhir. Selain itu, mahasiswa juga dapat mengunduh beberapa dokumen/form terkait tugas akhir (Gambar 6). Kalab juga dapat melihat pemetaan bidang keahlian pada lab yang dikepalainya (Gambar 7).

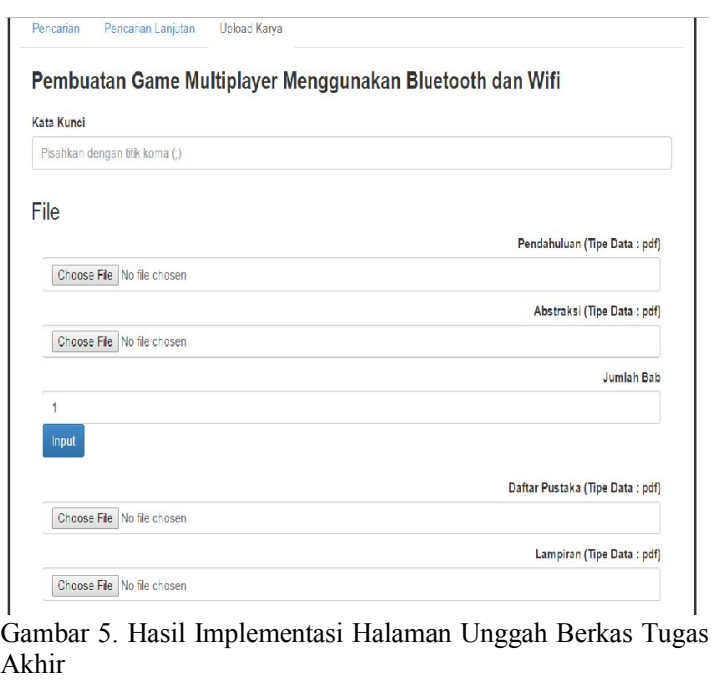




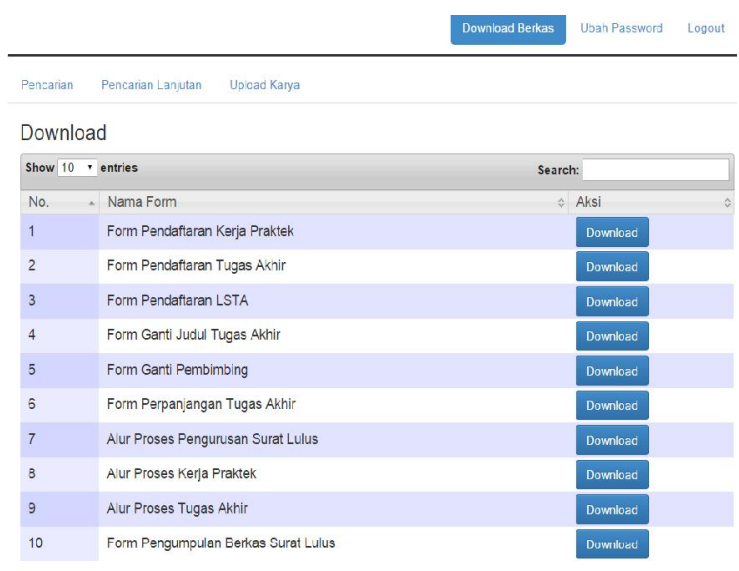

Gambar 6. Hasil Implementasi Halaman Unduh Dokumen Tugas Akhir

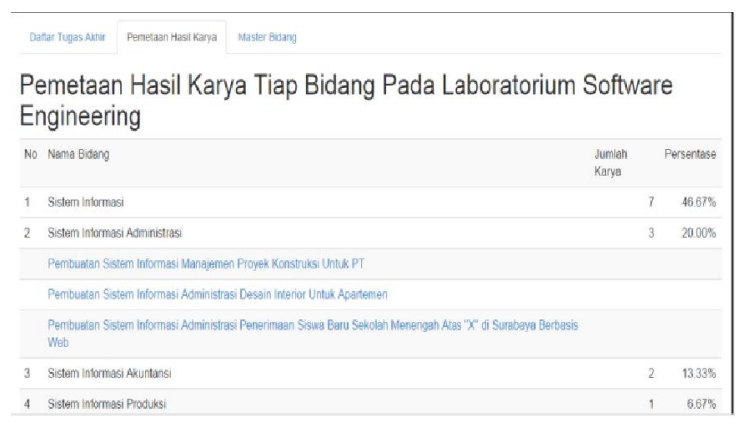

Gambar 7. Hasil Pemetaan Bidang Tugas Akhir pada Lab Tertentu

Untuk Fitur Pencarian Karya Tugas Akhir, digunakan fungsi peringkat Okapi BM25 untuk membuat ranking terhadap hasil karya sesuai relevansinya.

\section{IMPLEMENTASI FUNGSI OKAPI BM25}

Kualitas dari sistem pencarian informasi sangat bergantung pada fungsi pencarian yang mengembalikan kesamaan ukuran antara keyword query dengan dokumen (Russell \& Norvig, 2010). Proses pencarian akan mengurutkan dokumen berdasarkan nilai-nilai kesamaan dengan query. Dokumen yang memiliki peringkat tinggi diasumsikan sebagai dokumen yang relevan dengan query yang dicari. Pencarian topik Tugas Akhir pada penelitian ini berdasarkan query yang diinput oleh pengguna menggunakan metode pencarian fungsi Okapi BM25. Fungsi ini banyak digunakan oleh mesin pencari untuk memberi peringkat sekumpulan dokumen sesuai dengan query yang diberikan.

Dokumen yang mempunyai nilai fungsi tertinggi merupakan dokumen yang paling sesuai dengan query yang diberikan. Fungsi Okapi BM25 menghitung 3 faktor dalam penentuan peringkat dokumen terhadap query yang diberikan. Faktor pertama adalah TF (term frequency), yaitu jumlah kemunculan suatu kata yang dicari dalam sebuah dokumen. Semakin besar nilai TF dalam sebuah dokumen, maka nilai fungsi peringkat suatu dokumen semakin besar. Faktor kedua adalah IDF (invers document frequency of term), yaitu nilai invers dari total dokumen yang berisi kata yang dicari. Semakin besar nilai DF berarti semakin banyak dokumen yang memuat kata yang dicari. Artinya, semakin tinggi DF maka kata yang dicari kurang baik digunakan untuk memberi peringkat, karena kata tersebut merupakan kata umum ditemukan pada banyak dokumen. Oleh karena itu untuk perhitungan nilai fungsi peringkat digunakan nilai Inverse DF. Faktor ketiga adalah panjang dokumen, yaitu banyaknya kata dalam sebuah dokumen tertentu. Dokumen yang di dalamnya terdapat kata yang dicari dan mempunyai jumlah kata lebih sedikit akan lebih baik peringkatnya daripada dokumen mempunyai jumlah kata lebih banyak.

Fungsi Okapi BM25 untuk memberi peringkat dari $\mathrm{N}$ dokumen didefinisikan pada persamaan berikut : (Russell \& Norvig, 2010)

$$
\begin{aligned}
& \operatorname{BM} 25\left(d_{j}, q_{1: N}\right)= \\
& \sum_{i=1}^{N} \operatorname{IDF}\left(q_{i}\right) \cdot \frac{T F\left(q_{i}, d_{j}\right)(k+1)}{\operatorname{TF}\left(q_{i}, d_{j}\right)+k\left(1-b+b \frac{\left|d_{j}\right|}{L}\right)}
\end{aligned}
$$

dengan L dijabarkan pada persamaan berikut ini :

$$
L=\frac{\sum_{i}\left|d_{i}\right|}{N}
$$

Adapun fungsi IDF dapat dilihat pada persamaan berikut :

$$
\operatorname{IDF}\left(q_{i}\right)=\log \frac{N-D F\left(q_{i}\right)+0.5}{D F\left(q_{i}\right)+0.5}
$$

di mana qi adalah kata yang dicari, |dj| adalah panjang dokumen dj, banyaknya kata dalam dokumen dj, TF(qi,dj) adalah jumlah kemunculan kata qi dalam sebuah dokumen dj, IDF(qi), yaitu nilai invers dari total dokumen yang berisi kata qi, $\mathrm{L}$ adalah rata-rata panjang dokumen dari $\mathrm{N}$ dokumen. Terdapat dua parameter yang digunakan yaitu $\mathrm{k}$ dan $\mathrm{b}$ untuk proses evaluasi, nilai parameter yang biasa digunakan adalah $\mathrm{k}=2$ dan $\mathrm{b}=0.75$.

Pada tahun 2011, (Whissell \& Clarke, 2011) menggunakan Okapi BM25 dalam meningkatkan pengelompokan dokumen. Dengan menggunakan fungsi Okapi dengan komponen standar TF dan IDF menghasilkan peningkatan yang cukup signifikan terhadap hasil pengelompokan (cluster), sehingga fungsi Okapi BM25 dapat digunakan untuk meningkatkan kualitas pengelompokan dokumen (Whissell \& Clarke, 2011).

Dalam penelitian ini dilakukan beberapa tahapan proses dalam pembuatan fitur pencarian tugas akhir yang memanfaatkan fungsi Okapi BM25, terlihat pada Gambar 8. 


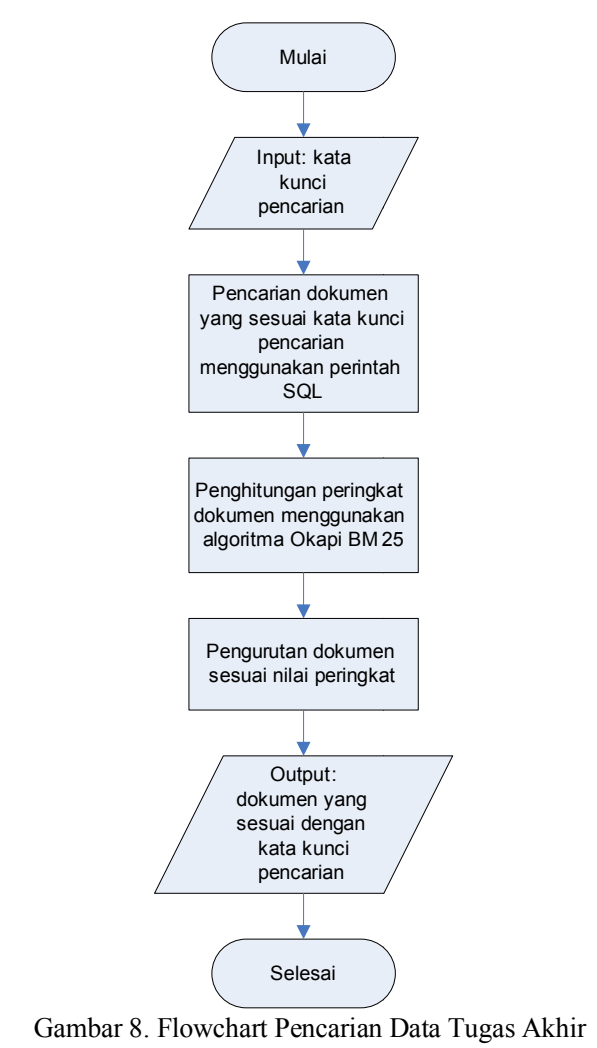

Dalam pencarian dokumen tugas akhir, user harus menginputkan kata kunci pencarian. Setelah user menginputkan kata kunci pencarian, maka input tersebut akan diolah dalam tiga proses sebagai berikut:

1. Proses pencarian dokumen-dokumen yang mempunyai kata kunci pencarian yang menggunakan perintah Structure Query Language (SQL). Proses pencarian ini dilakukan menggunakan basis data tugas akhir. Proses ini menghasilkan kumpulan dokumen yang di dalamnya terdapat kata kunci pencarian.

2. Proses selanjutnya adalah memberikan nilai peringkat untuk kumpulan dokumen yang didapatkan pada proses pertama. Pemberian nilai peringkat untuk setiap dokumen berdasarkan relevansi dokumen dengan kata kunci pencarian. Dokumen yang lebih relevan (sesuai) dengan kata kunci pencarian mempunyai nilai peringkat yang lebih besar dibandingkan dengan yang kurang relevan (sesuai). Penghitungan nilai peringkat dokumen terhadap kata kunci pencarian, menggunakan fungsi Okapi BM25. Fungsi Okapi BM25 memperhitungkan frekuensi setiap kata kunci pencarian di dalam kumpulan dokumen.

3. Proses berikutnya adalah mengurutkan dokumen berdasarkan nilai peringkat yang telah didapatkan pada proses kedua. Pengurutan dilakukan dengan mengurutkan secara ascending (pengurutan dari peringkat bernilai tinggi ke rendah). Peringkat terbesar berarti dokumen tersebut paling sesuai dengan kata kunci yang dicari. Dokumen yang ditampilkan sebagai hasil pencarian adalah dokumen yang telah urut berdasarkan peringkat kesesuaian dokumen dengan kata kunci pencarian.

Fungsi peringkat Okapi BM25 ini diimplementasikan dalam bentuk Fitur Pencarian Karya Tugas Akhir yang ada di dalam Sistem Repositori. Contoh implementasi Fitur Pencarian Karya Tugas Akhir dapat dilihat pada Gambar 9.

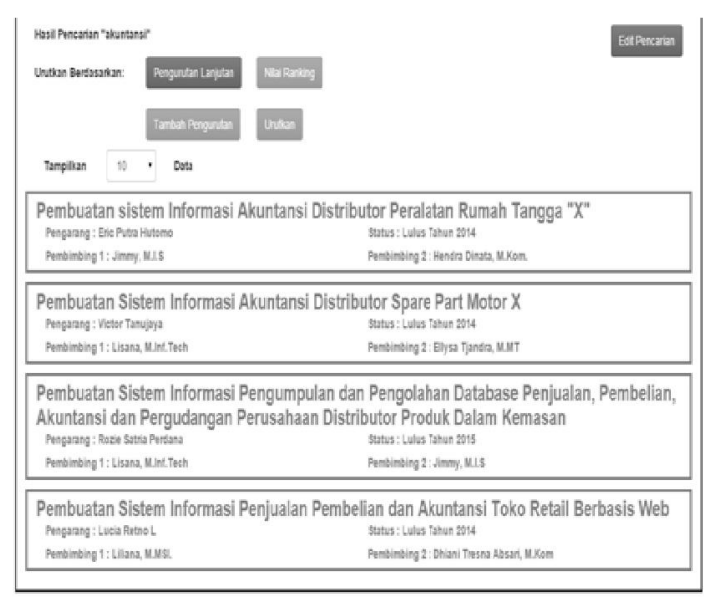

Gambar 9. Hasil Implementasi Tampilan Halaman Pencarian Karya Tugas Akhir

Pada Gambar 9, dokumen hasil pencarian ditampilkan secara urut berdasarkan hasil fungsi peringkat Okapi BM25. Contoh nilai peringkat dokumen hasil pencarian dapat dilihat pada Tabel I.

TABELI

HASIl Nilai PERINGKAT DARI Fungsi OKAPI BM25

\begin{tabular}{|c|l|c|}
\hline No & \multicolumn{1}{|c|}{ Judul Dokumen TA } & $\begin{array}{c}\text { Nilai } \\
\text { Peringkat }\end{array}$ \\
\hline 1 & $\begin{array}{l}\text { Pembuatan Sistem Informasi } \\
\text { Akuntansi Distributor Peralatan } \\
\text { Rumah Tangga "X" }\end{array}$ & 4.226 \\
\hline 2 & $\begin{array}{l}\text { Pembuatan Sistem Informasi } \\
\text { Akuntansi Distributor Spare Part } \\
\text { Motor X }\end{array}$ & 4.122 \\
\hline 3 & $\begin{array}{l}\text { Pembuatan Sistem Informasi } \\
\text { Pengumpulan dan Pengolahan } \\
\text { Database Penjualan, Pembelian, } \\
\text { Akuntansi dan Pergudangan } \\
\text { Perusahaan Distributor Produk Dalam } \\
\text { Kemasan }\end{array}$ & 3.540 \\
\hline 4 & $\begin{array}{l}\text { Pembuatan Sistem Informasi } \\
\text { Penjualan Pembelian dan Akuntansi } \\
\text { Toko Retail Berbasis Web }\end{array}$ & 2.634 \\
\hline
\end{tabular}

Ujicoba pencarian data tugas akhir dilakukan dengan cara membandingkan hasil proses pencarian karya tugas akhir yang menggunakan fungsi Okapi BM25 terhadap proses pencarian tanpa fungsi Okapi BM25. Proses pencarian dokumen dilakukan dengan cara mencari kata kunci pencarian pada basis data dokumen tugas akhir. Pencarian menggunakan fungsi Okapi BM25, dokumen yang ditampilkan akan diurutkan sesuai nilai peringkat fungsi Okapi BM25 pada dokumen berdasarkan kata kunci "akuntansi" pada 
basis data dokumen tugas akhir tersebut. Sedangkan proses pencarian tanpa menggunakan fungsi Okapi BM25 (hanya menggunakan SQL), maka proses pencarian akan menampilkan dokumen yang mempunyai kata kunci pencarian sesuai urutan nomor baris dokumen secara ascending pada tabel Tugas Akhir. No baris dokumen pada tabel Tugas Akhir hasil pencarian dengan kata kunci "akuntansi" dapat dilihat pada Tabel II beserta hasil perbandingannya. No baris dokumen pada tabel Tugas Akhir hasil pencarian ditampilkan di dalam tanda kurung ( ).

TABEL II

Perbandingan Hasil Pencarian

\begin{tabular}{|c|c|c|}
\hline \multirow{2}{*}{$\begin{array}{l}\text { Ur } \\
\text { ut } \\
\text { an }\end{array}$} & \multicolumn{2}{|c|}{ Judul dokumen } \\
\hline & $\begin{array}{c}\text { Dengan Fungsi Okapi } \\
\text { BM25 }\end{array}$ & $\begin{array}{c}\text { Tanpa Fungsi Okapi } \\
\text { BM25 }\end{array}$ \\
\hline 1 & $\begin{array}{c}\text { Pembuatan Sistem } \\
\text { Informasi Akuntansi } \\
\text { Distributor Peralatan } \\
\text { Rumah Tangga "X" (3) }\end{array}$ & $\begin{array}{c}\text { Pembuatan Sistem } \\
\text { Informasi Akuntansi } \\
\text { Distributor Peralatan } \\
\text { Rumah Tangga "X" (3) }\end{array}$ \\
\hline 2 & $\begin{array}{c}\text { Pembuatan Sistem } \\
\text { Informasi Akuntansi } \\
\text { Distributor Spare Part } \\
\text { Motor X (55) }\end{array}$ & $\begin{array}{c}\text { Pembuatan Sistem } \\
\text { Informasi Pengumpulan } \\
\text { dan Pengolahan } \\
\text { Database Penjualan, } \\
\text { Pembelian, Akuntansi } \\
\text { dan Pergudangan } \\
\text { Perusahaan Distributor } \\
\text { Produk Dalam Kemasan } \\
(44)\end{array}$ \\
\hline 3 & $\begin{array}{c}\text { Pembuatan Sistem } \\
\text { Informasi Pengumpulan } \\
\text { dan Pengolahan } \\
\text { Database Penjualan, } \\
\text { Pembelian, Akuntansi } \\
\text { dan Pergudangan } \\
\text { Perusahaan Distributor } \\
\text { Produk Dalam Kemasan } \\
(44)\end{array}$ & $\begin{array}{c}\text { Pembuatan Sistem } \\
\text { Informasi Penjualan } \\
\text { Pembelian dan } \\
\text { Akuntansi Toko Retail } \\
\text { Berbasis Web (45) }\end{array}$ \\
\hline 4 & $\begin{array}{c}\text { Pembuatan Sistem } \\
\text { Informasi Penjualan } \\
\text { Pembelian dan } \\
\text { Akuntansi Toko Retail } \\
\text { Berbasis Web (45) }\end{array}$ & $\begin{array}{c}\text { Pembuatan Sistem } \\
\text { Informasi Akuntansi } \\
\text { Distributor Spare Part } \\
\text { Motor X (55) }\end{array}$ \\
\hline
\end{tabular}

Pengurutan dokumen hasil pencarian menggunakan Okapi BM25 lebih baik dibanding hasil pencarian tanpa Okapi BM25 karena dokumen hasil pencarian diurutkan berdasarkan nilai kesesuaian kata kunci pencarian dengan dokumen.

\section{EVALUASI SISTEM}

Setelah pencarian karya tugas akhir selesai dibuat, maka dilakukan evaluasi dengan cara menampung masukan/saran dari pengguna sistem untuk memastikan bahwa sistem yang dibuat telah sesuai dengan tujuan. Untuk keperluan tersebut dilakukan wawancara terhadap tiap user role yang ada, meliputi dosen, mahasiswa, PAJ, Kalab, serta Kajur. Berikut ini adalah rekap hasil dari wawancara yang dilakukan.

Hasil wawancara terhadap mahasiswa :

1. Hasil pencarian dokumen tugas akhir sudah sesuai dengan kata kunci pencarian.
2. Pencarian dokumen tugas akhir membantu mahasiswa untuk melihat gambaran isi tugas akhir dari abstraksi, bab 1, screenshot, serta jurnal yang dapat dibaca.

3. Proses unggah tugas akhir membantu mahasiswa untuk mengunggah dokumen tugas akhir dengan lebih mudah.

4. Proses unduh berkas yang berkaitan dengan tata cara maupun form terkait tugas akhir sangat membantu mahasiswa mengetahui informasi berkaitan dengan tugas akhir.

5. Perlu ditambahkan beberapa pilihan dan keterangan untuk pengisian data pada proses unggah dokumen tugas akhir.

6. Perlu diperbaiki proses input yang lebih mudah untuk mengisi data software dan bidang keahlian pada saat unggah karya tugas akhir.

Hasil wawancara terhadap PAJ :

Fasilitas unggah berkas berkaitan dengan Tugas Akhir sangat membantu PAJ dalam menyebarkan informasi mengenai tugas akhir.

Hasil wawancara terhadap dosen :

1. Daftar tugas akhir yang ditampilkan sudah membantu dosen dalam melihat dan mencari data tugas akhir.

2. Menu verifikasi tugas akhir membantu dosen untuk melakukan proses verifikasi dokumen tugas akhir

3. Menu unduh berkas membantu dosen untuk mengunduh berkas jadwal tugas akhir.

4. Hasil pencarian dokumen tugas akhir sudah sesuai dengan kata kunci pencarian.

5. Pencarian dokumen tugas akhir membantu dosen untuk mengetahui isi tugas akhir yang sudah tersimpan, karena dosen dapat melihat detil dokumen tugas akhir yang ada.

Hasil wawancara terhadap Kalab:

1. Hasil pemetaan tugas akhir membantu Kalab untuk mengetahui data tugas akhir yang berada di laboratoriumnya sesuai bidang keahlian pada laboratorium tersebut.

2. Tampilan hasil pemetaan setiap bidang sebaiknya dilengkapi dengan grafik agar mudah dilihat.

3. Daftar tugas akhir yang ditampilkan sudah membantu kepala laboratorium dalam melihat dan mencari data tugas akhir.

4. Menu verifikasi tugas akhir membantu Kalab untuk melakukan proses verifikasi dokumen tugas akhir.

5. Menu unduh berkas membantu Kalab untuk mengunduh berkas jadwal tugas akhir.

6. Hasil pencarian dokumen tugas akhir sudah sesuai dengan kata kunci pencarian.

7. Perlu ditambahkan navigasi no urut dari hasil pencarian. 
Hasil wawancara terhadap Ketua Jurusan :

1. Hasil pemetaan tugas akhir membantu Kajur untuk mengetahui kategorisasi data tugas akhir pada setiap laboratorium yang ada di jurusan.

2. Hasil pencarian data tugas akhir membantu dalam proses pencarian Tugas Akhir.

\section{KESIMPULAN}

Berdasarkan hasil penelitian, diperoleh kesimpulan bahwa sistem repositori tugas akhir ini memberikan kemudahan bagi mahasiswa dan PAJ untuk mengunggah karya tugas akhir berkas terkait tugas akhir. Hasil pemetaan karya tugas akhir sesuai bidang keahlian laboratorium juga dapat membantu Kalab dan Kajur untuk mengetahui bidang keahlian dari semua karya tugas akhir yang ada. Selain itu, proses pencarian dokumen menjadi lebih relevan dengan penggunaan fungsi peringkat Okapi BM25.

\section{DAFTAR PUSTAKA}

Bernstein, P. A., \& Dayal, U. (1994). An Overview of Repositori Technology. the 20th International Conference on Very Large Data Bases (pp. 705-713). San Francisco: Morgan Kaufmann Publishers.

Dima, E., Henrich, V., Hinrichs, E., Hinrichs, M., Hoppermann, C., Trippel, T., et al. (2012). A Repository for the Sustainable Management of Research Data. The eighth international conference on Language Resources and Evaluation (LREC) (pp. 3586-3592). Istanbul : ELRA (European Language Resource Association).

Gavrilis, D., Angelis, S., \& Papatheodorou, C. (2010). Mopseus - A Digital Repositori System With Semantically Enhanced Preservation Services. 7th International Conference on Preservation of Digital Objects (pp. 34-41). Vienna: Technical University of Vienna.

Russell, S., \& Norvig, P. (2010). Artificial Intelligence: A Modern Approach, 3rd Edition. New Jersey: Prentice Hall.

Whissell, J. S., \& Clarke, C. L. (2011). Improving document clustering using Okapi BM25 feature weighting. Information Retrieval , 14 (5), 466-487. 